\title{
The Interbank Market in Kenya: An Event-Based Stress Analysis Based on Treasury Bill Market
}

\author{
Jared Osoro \\ David Muriithi \\ Kenya Bankers Association, \\ Centre for Research on Financial Markets and policy ${ }^{\circledR}$
}

doi: 10.19044/esj.2017.v13n16p127 URL:http://dx.doi.org/10.19044/esj.2017.v13n16p127

\begin{abstract}
This paper seeks to explore nexus between the volatility in the Kenyan interbank market and Treasury bill market in the event of market distress arising from collapses of a lender. Three stress triggering events are defined; -the placement of Dubai Bank, Imperial Bank and Chase Bank placement under receivership. The inclusion of Treasury bill market is aimed to ascertaining whether then Central Bank's intervention in the market to correct inefficiency in the interbank market upon the collapse of a lender is either proactive or reactive. The EGARCH and TGARCH were used to model the relationship. Key finding of the study is that 91-Day Treasury bill rate positively and significantly affects the interbank market rate with the effect doubling in the wake of bank collapse.
\end{abstract}

Keywords: Interbank, Volatility Clustering, GARCH models and leverage effect

\section{Introduction}

The role of the interbank market in any economy is critical in allocation of liquidity from banks with surplus to the banks facing liquidity deficit. Shocks in the interbank market caused by liquidity stress are impediments for an efficient interbank market. These shocks lead to volatility in the interbank market as could be seen in the interbank traded volumes and interbank rates. In the worst scenario, these shocks bring distortions that could lead to increased costs of participating in the interbank market. When the shocks to the interbank market are system-wide, the central bank assumes an intermediary function between liquidity surplus banks and liquidity deficit banks. We posit that by doing so, the central bank takes a reactive intervention as opposed to a proactive role in restoring effectiveness in the interbank market. Such interventions could 
arise in the wake of a bank run, collapse of a bank, placement of a bank under statutory management among others. Unlike other components of the financial markets that are typically analysed in the context of their interface with the wider economy, the interbank market is often seen in the narrow context as an exclusive banking industry market. In that regard, the critical role of the inter-bank market in ensuring stability is understated. It is therefore for these reasons that central banks focus on the interbank markets in implementing monetary policy.

However, despite the crucial role of interbank markets in any financial system, relatively littles attention has been accorded to them. According to Allen and Gale (2009), the existing empirical work on interbank markets seems to focus more on inefficiencies arising from incompleteness of interbank markets. For instance, Frexias et al (2009) looks at interbank market integration under asymmetric information asserting that by setting interest rates that depend on pattern of idiosyncratic risk shocks the government can implement constrained efficient allocation of credit in the market. Studies by Holmstrom and Tirole (1998), Gorton and Huang (2004, 2006), Diamond and Rajan (2005, 2008), and Acharya and Yorulmazer (2008) assert that in financial markets where markets for liquidation do not work properly or are absent some form of government intervention may improve efficiency. This informs our choice for Treasury bill which is both a market tool and a policy tool. Such studies in the Kenyan Market are missing.

For this reason, this paper seeks to put a spotlight on Kenya's interbank market, particularly how it operates during periods characterised by stress. More specifically, the paper looks at how the interbank market volatility is affected by financial stress arising from a bank failure. Secondly, the paper explores the transmission between the interbank market rate and the Treasury bill rate in the event of bank failure. This second objective therefore focuses as to whether the Central Bank intervention in the credit market in the event bank failure is reactive or proactive in managing the interbank market volatility. Therefore the two main questions addressed by this paper are: How does the volatility in Kenya's interbank market call rate change with the events of three commercial bank failure namely Dubai bank, Imperial bank and Chase bank? Secondly, is there transmission between interbank market rate and the Treasury bill rate in the event of the three commercial bank failures? Answering these two pertinent questions fills in the gap on the scanty information on the area. Currently a number of studies have been conducted on Kenya's interbank market. However no study seems to have been carried out on the effects of the current bank failures on the volatility of the interbank market call rates. This is perhaps on the backdrop that the collapse of Dubai, Imperial and Chase bank is a recent phenomenon. 
Secondly, there lacks a local empirical study on the how the Central bank intervention through the open market operation tools such as Treasury bills in the wake of bank failure affects interbank market volatility. Lastly is the scarcity of empirical studies on the transmission between the interbank market call rates and the Treasury bill rates in the presence of the recent three bank failures. By filling in these gaps the study contributes to policy in a number of ways. One of such contributions is on the issues as to whether, the Central bank intervention in the credit market via open market operation in the wake of bank failure help to resolve the structural inefficiencies of the interbank market. This is informed by the transmission between the interbank call rates and the Treasury bill rates. To the existing literature, this paper add to the body of knowledge by going beyond modelling of the interbank market rate volatility to linking such volatilities on specific events on bank failures. This shed lights into how interbank market volatility changes in the collapse of small bank (Dubai bank) as opposed to a collapse of medium sized bank (Chase bank and Imperial bank). By the same symmetry, the paper adds to existing literature on the transmission between interbank market rates and Treasury bill rate by extending such transmissions to specific bank failure dates. This way it informs on what is the nature of transmission between the two rates in the event of collapse of a tier three bank (Dubai bank) as compared to a collapse of tier two bank (Imperial and Chase bank).

Our modelling of the transmission between interbank rate and Treasury bill rate is hinged on the work of Allen and Gale (2009) in their analysis of interbank market liquidity and central bank intervention. According to them, inadequate opportunities for banks to hedge idiosyncratic risk and the aggregate liquidity shocks, there tend to exist excessive price of volatility in the interbank market. In such phenomenon, central bank can intervene in the credit market via implementation of constrained efficient allocation using open market operations to fix the short term interest rates. One of such tools would be treasury bills.

\section{Why the interbank market in Kenya}

Analyses of Kenya's interbank market have tended to focus on its linkages to monetary policy conduct (Oduor, et. al., 2014; Alper, 2016, et. al.). The linkages are explored on the back of the inter-bank being considered to be not only inefficiency but also segmented. While the inefficiency characteristic of the interbank market in the context of Kenya would be attributable to the relativity of market depth compared to those markets considered to be close to efficient, segmentation is a function of market structure and is therefore not unique.

Stylised characterisation of interbank markets that underpin 
theoretical and empirical studies (Kim, 2014) draw on the "small-bank""big-bank" dichotomy. Three outcomes point toward the odds typically being against small banks: First is that big banks lend to each other at a rate close to the central bank target rate. Second is that a small bank borrowing from a big bank tends to pay a higher rate than central bank target rate while if the small bank was lending to a big bank, it will get a lower rate than the central bank target rate. Thirdly is that a small bank trading with a big bank will only get more favourable terms for larger loans.

These three characteristics are nuanced in the Kenyan case, cognisant that the policy signalling ability of the interbank rate is constrained by inefficiency and segmentation attributes. We therefore contextualise the Kenyan market along three characteristics: One, banks in the "big" category - to the extent that size is perceived to be a basis for quality - lend to each other at less limiting terms that they do to "small" banks. This view is aligned to Kim (2014).Two, the interbank network structure is asymmetrical such that "big" banks often have opportunity for access relationships across the industry while "small" banks do not. The ease of access is enhanced if a bank belongs to a regional or international network, a perspective highlighted by Deb (2016) in a comparison between belonging to different networks and creating a related party network. In other words the benefits of multimarket banking as envisaged in Berrospide, et. al., (2016) go beyond spreading credit and funding risks to include boosting interbank market access at the local level. Lastly, in the event of flight to quality - and if the perspective is that size and quality have a positive correlation - banks in the "small" category are subject to the access, not even cost, squeeze.

By seeking to understand the interbank market beyond its relationship with monetary policy conduct, this paper enhances the appreciation of the market when it is distressed. Such appreciation is often masked when the market is superficially assessed based on the volume-price tracking. As Figure 1 shows, the recent evolution of the Kenyan interbank market shows 'normal' market behaviour. In reality, the market has been far from normal. In the recent episodes three banks, considered "small" under the "small bank - big bank" dichotomy, were placed under receivership by the Central Bank of Kenya (CBK) anchor this paper's analytical stress triggers. As Kim (2014) observes, the disadvantage that small banks experience in the interbank market during a crisis can largely be explained by a shift in the liquidity cost, rather than by changes in loan supply and demand. In the Kenyan case, such distress could be seen to be beyond costs; in stances there has been obvious supply cuts that cannot be observed from the aggregated datasets.

In order to unmask the interbank market, we step back and looks at the basics of why the interbank market exists in the first place. We then trace 
the linkages between the inter-bank market and other markets with a view to assessing whether the signal of distress could be picked from another price besides the interbank rate. The conceptual thinking of looking for the distress signal of one money market price in another money market price is motivated by Dornbusch (1976) seminal analysis and especially its core observation that financial markets are dynamic to the extent of the that prices of relatively more liquid financial assets adjusting much faster than goods' prices or even other financial assets such as loans.

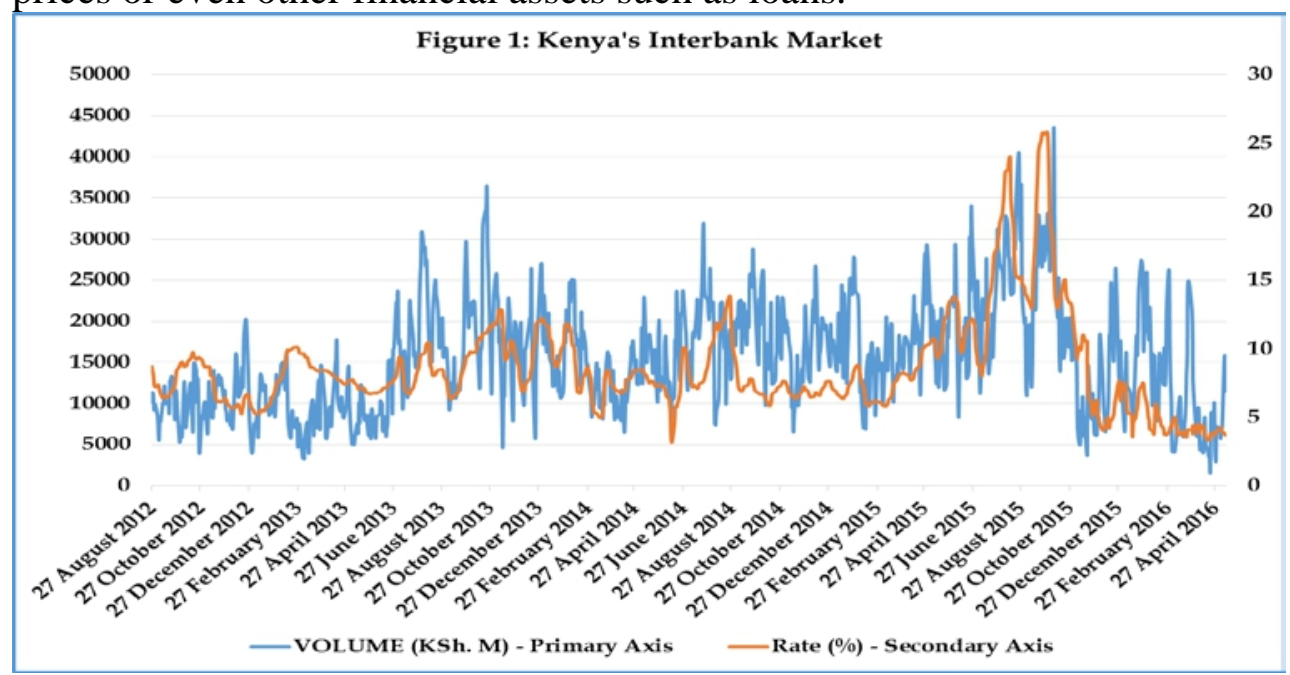

Source: Central Bank of Kenya

The interbank market could aptly be described as a liquidity coinsurance market (Castiglionesi, et. al., 2014). Banks are typically exposed to liquidity risks by virtue of the fact that they transform short-term liquid liabilities to long-term illiquid assets. To manage the risk, they hold reserves as a self-insurance mechanism. Reserves however present a cost to banks as they forgo income by not investing in risky assets that are illiquid or at the very least near-liquid assets such as short-tenor government securities. Banks therefore participate in the interbank market where they exchange resources with each other thus co-insuring themselves against liquidity risks. The existence of the interbank market by no means imply that the ensuing coinsurance offers a full solution to liquidity challenges. The interbank solution to liquidity challenges becomes at best partial, considering that liquidity challenges could be systemic, in which case it is impossible to co-insure. Furthermore, the interbank market being typically an over-the-counter affair means that it hinges on pre-established connections that could be limited; this makes it hard to co-insure liquidity risks if there are no pre-established connections or they have been severed. As an alternative, banks could resort to capital holders to whom they will adjust the pay-out; in essence banks 
could transfer part of the liquidity uncertainty to capital holders, this itself being costly because capital to banks also comes at a cost. The foregoing rationale for the existence of the interbank market as well as the alternatives in the form of reserves and capital with the attendant costs, are instructive on how to approach the understanding of the recent distress in interbank market in Kenya following three episodes namely placing of receivership of Dubai Bank Limited on $13^{\text {th }}$ August 2015, Imperial Bank Limited on $15^{\text {th }}$ October 2015 and Chase Bank Limited on $7^{\text {th }}$ March 2016. These episodes point towards three linked observations that are key to this paper's objective. This informs the first objective of the paper which is the effect of financial stress arising from bank failure on the credit market volatility.

First, pre-existing connections at a bilateral level were severely tested to the disadvantage of "small banks", which are manly borrowers in the interbank market. It didn't help that the "small banks" experienced capital flight as could be confirmed by the CBK on April 2016 when it availed a liquidity support framework for commercial and microfinance banks following market linked to the placement of Chase Bank Limited under receivership. Under the circumstances, the lender banks in the interbank market considered the Treasury Bills market as an alternative. Second, the challenges associated with the three banks - whose common characteristics are that they were all local banks without foreign principals and were not in the "big-bank" category - were not considered to be systemic in the sense of affecting the general stability of the Kenyan banking industry. In any case pinning systemic risks to a given institution is not easy (Danielsson et. al., 2016). Nonetheless, the effect on the interbank market has been systemwide. Third, there is no evidence to suggest that the liquidity challenges observed and the ensuing system-wide effect on the interbank market have led to a capital response from shareholders; in any case such response requires more time.

These observations motivate the search for a signal alternative to the interbank rate to guide gauge the persistence or lack thereof of distress following market disturbance. Given the first observation, this paper hypothesises that the alternative signal can be picked from the shortest tenor of the Treasury Bills market. The hypothesis stems from two factors. One, there is a very close association between the interbank rates and the 91-Day Treasury Bill rates (Figure 2). 


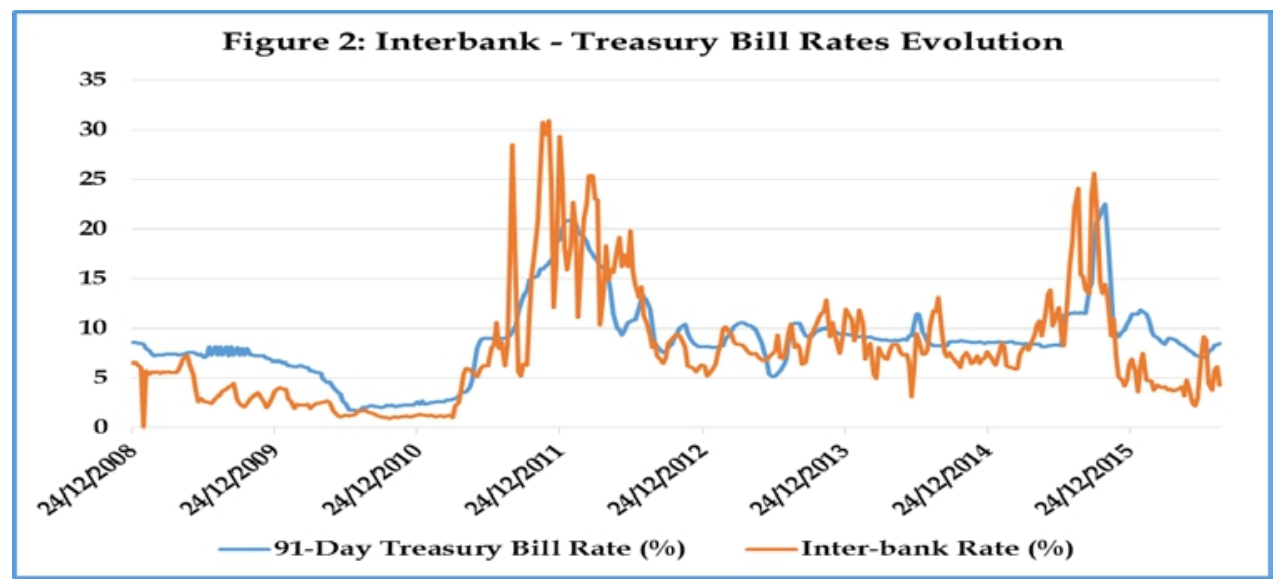

Source: Central Bank of Kenya

Two, the Treasury Bills have both policy and market inclinations. To the extent it is associated with Government resource requirements as triggered by the fiscal policy stance, the Treasury Bills market could have a big influence on the overall market liquidity as the government is arguably a major market player. A rise in the Treasury Bill rate could be interpreted as signal of tight liquidity conditions owing to the Government presence the market. The policy angle arises from the fact that CBK Monetary policy actions could somewhat be influence by the Governments fiscal action, a phenomenon called fiscal dominance. It is recognised that the CBK can influence liquidity in the market by way of repurchase orders (Repos). When banks have liquidity shortage, they can borrow from the CBK at the Repo rate - the rate at which the central bank lends short-term money to the banks against securities. A reduction in the Repo rate helps banks get money at a cheaper rate. The reverse repo rate - the rate at which the banks maintain surplus funds with CBK signals the level of liquidity surplus in the market. The reverse Repo rates have almost perpetually been zero. This is by no means suggestive of no instances of liquidity abundance in the market; instead it is suggestive of the limitations of using the Repo and reverse Repo rates as a signal of liquidity distress or abundance. This informs the second objective of the paper which is the transmission between interbank market and Treasury bill market in the event of a bank failure.

The next section of this paper specifies the model for the empirical assessment of the extent to which the Treasury Bills market reveals the nature of distress in the interbank market. The assessment is undertaken around three recent episodes of bank failures that distressed the interbank market at varying degrees. The empirical results are reported in the following section, upon which conclusions and policy inferences are made in the final section. 


\section{Methodology}

The paper models the nexus between interbank market volatility and Treasury Bill Market performance in the event of collapse of the lender by applying the ARCH family models given that the study deals with high frequency data which is on weekly basis. More specifically, the Exponential Generalized Autoregressive Conditional Heteroscedastic (EGARCH) by Nelson (1991) and Threshold Generalized Autoregressive Conditional Heteroscedastic (TGARCH) model by Zakoian (1994) which is ideal for capturing information asymmetry in financial data. In this case they will be the ideal models for capturing information asymmetry in the credit markets both in the interbank and Treasury bill market in the event of a bank failure.

The setting of the study is that it's an event based study. Three events of distress are defines in the study. First, is the collapse of Dubai bank on 14th August 2015, secondly is the collapse of Imperial banks on 13th October 2015 and thirdly the collapse of Chase bank on 7th April 2016. Given that financial markets are driven by news we define the event to be one month prior to the actual announcement date of placing the bank under receivership. Given that the effect of the closure of the three banks was not concluded as at September 2016, it's presumed that the events continue to influence the credit market. As such the end dates for the events are undefined. Based on the three events of bank collapse, we define five period. First is the period prior to the collapse of Dubai bank (period 1), period after collapse of Dubai bank (period 2), period between the collapse of Dubai bank and collapse of Imperial banks (period 3), period between collapse of imperial bank and collapse of Chase bank (period 4) finally the overall period that account for the entire study period. To test the effect of financial stress on the interbank market volatility, an event based analysis is employed in which three dummies are created namely: dummy Dubai, dummy Imperial and dummy Chase for the respective closure of the Dubai, Imperial and Chase bank. However, in order to test for the transmission between the interbank market and the Treasury bill market, a bivariate GARCH was applied. In this case, the interbank call rate was used to reflect the supply and demand patterns of bank reserves thus sending a signal to the Central banks to intervening in the credit market upon understanding of the market pressure. One of this interventions is through the open market operations where Treasury bill are frequently used having the shortest tenure.

Upon definition of the five period, the EGARCH and TGARCH models are estimated. First, the regressions of the three events of distress are done separately. Further regression of the overall combination the three events of distress which combine the collapse of the three banks.

The Exponential Generalized Autoregressive Conditional Heteroscedastic (EGARCH) by Nelson (1991) and Threshold Generalized 
Autoregressive Conditional Heteroscedastic (TGARCH) model by Zakoian (1994) are defined as follows:

The EGARCH and TGARCH models for interbank rates as follows:

$$
\begin{aligned}
& I R_{t}=\alpha+I R_{t 1}+T B R+\varepsilon \\
& \operatorname{Ln}\left(\mathrm{h}_{\mathrm{t}}\right)=\operatorname{Ln} \sigma_{\mathrm{t}}^{2}=\omega+\sum_{j=1}^{p} \beta_{j} \operatorname{Ln}\left(\sigma_{t-j}^{2}\right)+\sum_{i=1}^{q} \alpha_{i}\left\{\left|\frac{\varepsilon_{t-i}}{\sigma_{t-i}}\right|-\sqrt{\frac{2}{\pi}}\right\}-\gamma_{i} \frac{\varepsilon_{t-i}}{\sigma_{t-i}}
\end{aligned}
$$

Where:

$I R_{t}$ Is the current week interbank rate

$I R_{t-1}$ Is the previous week interbank rate

TBR is the 91-DayTreasury Bill Rates

$$
\varepsilon_{t} \text { is the error term for the model }
$$

$h_{t}=\sigma_{t}^{2}$ is the variance for the model

Model 1 is the mean equation while model 2 is the variance equation for the EGRACH model.

Similarly, we specify our TGARCH model as follows:

$$
I R_{t}=\alpha+I R_{t-1}+T B R+\varepsilon_{t}
$$

$h_{t}=\sigma_{t}^{2}=\omega+\alpha_{1} \varepsilon_{t-1}^{2}+\gamma d_{t-1} \varepsilon_{t-1}^{2}+\beta_{1} \sigma_{t-1}^{2}$

Where $d_{t-1}$ is a dummy where

$$
d_{t-1}=\left\{\begin{array}{l}
O \text { if } \varepsilon_{t-1}<O, \text { bad news } \\
1 \text { if } \varepsilon_{t-1} \geq 0, \text { good news }
\end{array},\right.
$$

Model 3 is the mean equation while model 4 is the variance equation for the TGRACH model.

Bad news here refers to placement of a bank under statutory management while good news would refer to the revival of the lender who has been under statutory management. Model 3 is the mean equation while model 4 is the variance equation for the TGARCH model. As stated earlier, this paper adopt a dual analysis approach unlike a one sided analysis approach. With this regard, therefore we acknowledge that what happens in the interbank market influences the open market operations in management of liquidity challenges in the market. By the same symmetry we specify our EGARCH and TGARCH models for Treasury bill market as follows:

$$
T B R_{t}=\alpha+T B R_{t 1}+I R+\varepsilon_{t}
$$

$$
\operatorname{Ln}\left(\mathrm{h}_{\mathrm{t}}\right)=\operatorname{Ln} \sigma_{\mathrm{t}}^{2}=\omega+\sum_{j=1}^{p} \beta_{j} \operatorname{Ln}\left(\sigma_{t j}^{2}\right)+\sum_{i=1}^{q} \alpha_{i}\left\{\left|\frac{\varepsilon_{t i}}{\sigma_{t-i}}\right| \quad \sqrt{\frac{2}{\pi}}\right\} \quad \gamma_{i} \frac{\varepsilon_{t i}}{\sigma_{t-i}} .
$$

Model 5 is the means equation while model 6 is the variance equation for the EGARCH model. 


$$
\begin{aligned}
& T B R_{t}=\alpha+T B R_{t 1}+I R+\varepsilon_{t} \ldots \ldots \ldots \ldots \ldots \ldots \ldots \ldots \ldots \\
& \mathrm{h}_{\mathrm{t}}=\sigma_{t}^{2}=\omega+\alpha_{1} \varepsilon_{t-1}^{2}+\gamma d_{t 1} \varepsilon_{t-1}^{2}+\beta_{1} \sigma_{t-1}^{2}
\end{aligned}
$$

Model 7 is the means equation while model 8 is the variance equation for the TGARCH model.

\section{Data}

The study employs high frequency data in the analysis. Weekly data on the interbank market call rates and Treasury bill rate are applied in modelling the effect of the financial distress arising from the closure of Dubai, Imperial and Chase bank on the interbank market call rates as well as testing for the transmission between interbank market call rates and Treasury bill rates. The choice of the weekly data is informed by the fact that the 91 Treasury bill data is available on weekly basis and not on the daily basis as the interbank market rate data. For the interbank rate the average weekly call rate is used. The study covers the period between December 2008 and August 2016.

\section{Results and Discussion}

In analysis, period 1 represent the period from December 2008 to one month priory to announcement of receivership of Dubai bank. Period 2 is the period after Dubai bank collapse but prior to Imperial bank collapse. Period 3 is after collapse of Imperial bank but before collapse of Chase bank. Period 4 is after collapse of Chase bank. All the periods from period 2 are consecutive to each other. From the descriptive statistics the mean interbank call rate increases with the collapse of Dubai bank but decline with collapse of Imperial and Chase bank accordingly. Similar trends are reported for standard deviation with the deviations from mean interbank call rate rising after Dubai bank closures and falling with the collapse of Imperial and Chase bank. On normality, it's evident that the interbank call rates become more non-normally distributed with the successive bank failures after Dubai bank closure as captured by Kurtosis values.

Table 1.0 Summary statistics for Interbank Call Rates

\begin{tabular}{|c|c|c|c|c|}
\hline & Period 1 & Period 2 & Period 3 & Period 4 \\
\hline Mean & 7.8319 & 8.1115 & 8.0018 & 7.8380 \\
\hline Std. Dev. & 5.8344 & 6.0580 & 5.9236 & 5.8383 \\
\hline Skewness & 1.5380 & 1.4364 & 1.4854 & 1.5438 \\
\hline Kurtosis & 5.7945 & 5.1849 & 5.4118 & 5.6373 \\
\hline Observations & 339 & 348 & 373 & 392 \\
\hline
\end{tabular}


Table 2.0 Summary statistics for Treasury Bill Rates

\begin{tabular}{|c|c|c|c|c|}
\hline & Period 1 & Period 2 & Period 3 & Period 4 \\
\hline Mean & 8.5012 & 8.6700 & 8.8665 & 8.8222 \\
\hline Std. Dev. & 3.8696 & 4.0057 & 4.0015 & 3.9690 \\
\hline Skewness & 0.8175 & .83532 & 0.8686 & 0.9176 \\
\hline Kurtosis & 4.5535 & 4.4071 & 4.5382 & 4.7750 \\
\hline Observations & 339 & 348 & 373 & 392 \\
\hline
\end{tabular}

Table 3.0 Covariance matrix interbank rates and Treasury bill rates

\begin{tabular}{|c|c|c|}
\hline & Interbank Rate & Treasury Bill Rate \\
\hline Interbank Rate & 1.0000 & 0.7917 \\
\hline Treasury Bill Rate & 0.7917 & 1.0000 \\
\hline
\end{tabular}

The covariance matrix between the squared interbank market rate and Treasury bill returns correlation of 0.7917 evidence a strong positive correlation with a implying that the two rates move together in same direction.

The financial sector stress periods is captured by the period in which three banks were placed under receivership. In this case we had period 1 which is the period from January 2009 but before the placement of any bank under receivership, period 2 captures the period when Dubai bank was place under receivership, period 3 captures the time when Imperial bank was placed under receivership while period 4 captures the period when chase bank was placed under receivership. Period 5 captures all the three stress period in the banking industry, with the analysis period being January 2009 to August 2016.

Table 4.0 Unit root test

\begin{tabular}{|l|l|l|l|l|}
\hline & \multicolumn{3}{|l|}{ With Intercept } & \multicolumn{2}{l|}{ With Intercept and Trend } \\
\hline ADF test statistics & $\begin{array}{l}\text { Calculated } \\
\text { Values }\end{array}$ & $\begin{array}{l}\text { Critical } \\
\text { Values }\end{array}$ & $\begin{array}{l}\text { Calculated } \\
\text { Values }\end{array}$ & Critical Values \\
\hline Interbank Call Rate (R) & -29.936 & $-3.432($ at $1 \%)$ & -29.931 & -3.961 (at 1\%) \\
\hline & & $-2.862($ at 5\%) & & -3.411 (at 5\%) \\
\hline & & $\begin{array}{l}-2.567 \quad(\text { at } \\
10 \%)\end{array}$ & & -3.127 (at 10\%) \\
\hline AR & & $-3.432($ at 1\%) & -29.928 & -3.961 (at 1\%) \\
\hline & -29.932 & $-2.862($ at 5\%) & & $-3.411($ at 5\%) \\
\hline
\end{tabular}

The test for stationarity is based on the Box and Jenkins (1976). Following this test the use of the dickey fuller test for unit root reveals that the weekly interbank call rates are integrated of order zero implying the absence of unit root. 
Table 5.0: Exponential GARCH results for interbank market volatility analysis

\begin{tabular}{|c|c|c|c|c|c|}
\hline \multicolumn{6}{|c|}{ EGARCH $(1,1)$ Results } \\
\hline \multicolumn{6}{|c|}{ Mean Equation } \\
\hline & Period 1 & Period 2 & Period 3 & Period 4 & Overall model \\
\hline Constant & $\begin{array}{l}0.0739 * * \\
(0.0442)\end{array}$ & $\begin{array}{c}-0.0860 * * * \\
(0.0095)\end{array}$ & $\begin{array}{l}0.0765^{* *} \\
(0.0115)\end{array}$ & $\begin{array}{l}0.0637 * * \\
(0.0463)\end{array}$ & $\begin{array}{c}0.1134 * * * \\
(0.0013)\end{array}$ \\
\hline Interbank (-1) & $\begin{array}{c}0.9196 * * * \\
(0.0000)\end{array}$ & $\begin{array}{c}0.9312 * * * \\
(0.0000)\end{array}$ & $\begin{array}{c}0.9186 * * * \\
(0.0000)\end{array}$ & $\begin{array}{c}0.9225^{* * *} \\
(0.0000)\end{array}$ & $\begin{array}{c}0.9362 * * * \\
(0.0000)\end{array}$ \\
\hline Treasury bill rate & $\begin{array}{c}0.0373 \\
(0.0184) \\
\end{array}$ & $\begin{array}{c}0.0677^{* * *} \\
(0.0000)\end{array}$ & $\begin{array}{c}0.0635^{* * *} \\
(0.0088) \\
\end{array}$ & $\begin{array}{l}0.0606 * * \\
(0.0159) \\
\end{array}$ & $\begin{array}{c}0.0358 \\
(0.0095) \\
\end{array}$ \\
\hline Dummy Dubai & & $\begin{array}{c}-1.0286 * * \\
(0.0560)\end{array}$ & & & $\begin{array}{l}-1.1793 \\
(0.3917)\end{array}$ \\
\hline Dummy Imperial & & & $\begin{array}{c}-0.1471^{* *} \\
(0.0490)\end{array}$ & & $\begin{array}{l}-1.2576 \\
(0.3671)\end{array}$ \\
\hline Dummy Chase & & & & $\begin{array}{c}0.0328 \\
(0.8740)\end{array}$ & $\begin{array}{c}0.0874 \\
(0.7160)\end{array}$ \\
\hline \multicolumn{6}{|c|}{ Variance Equation } \\
\hline Constant & $\begin{array}{c}- \\
0.4285^{* * *} \\
(0.0000)\end{array}$ & $\begin{array}{c}-0.3633^{* * *} \\
(0.0000)\end{array}$ & $\begin{array}{c}-0.4283 * * * \\
(0.0000)\end{array}$ & $\begin{array}{c}-0.4617 * * * \\
(0.0000)\end{array}$ & $\begin{array}{c}-0.4506 * * * \\
(0.0000)\end{array}$ \\
\hline $\mathrm{ARCH}(1)\left(\alpha_{1}\right)$ & $\begin{array}{c}0.6116^{* * *} \\
(0.0000)\end{array}$ & $\begin{array}{c}0.4970 * * * \\
(0.0000)\end{array}$ & $\begin{array}{c}0.6307 * * * \\
(0.0000) \\
\end{array}$ & $\begin{array}{c}0.6650 * * * \\
(0.0000)\end{array}$ & $\begin{array}{c}0.6382 * * * \\
(0.0000)\end{array}$ \\
\hline Asymmetry $(\gamma)$ & $\begin{array}{l}0.0381^{* *} \\
(0.0297)\end{array}$ & $\begin{array}{c}0.1762 * * * \\
(0.0015) \\
\end{array}$ & $\begin{array}{c}0.1706 \\
(0.1943) \\
\end{array}$ & $\begin{array}{c}0.1574 \\
(0.2718) \\
\end{array}$ & $\begin{array}{c}0.1035 \\
(0.0895) \\
\end{array}$ \\
\hline GARCH $(1)(\beta)$ & $\begin{array}{c}0.9405^{* * *} \\
(0.0000)\end{array}$ & $\begin{array}{c}0.9568 * * * \\
(0.0000)\end{array}$ & $\begin{array}{c}0.9679 * * * \\
(0.0000)\end{array}$ & $\begin{array}{c}0.9739 * * * \\
(0.0000)\end{array}$ & $\begin{array}{c}0.9665 * * * \\
(0.0000)\end{array}$ \\
\hline Dummy Dubai & & $\begin{array}{l}0.3335 * \\
(0.0744)\end{array}$ & & & $\begin{array}{c}0.3100 \\
(0.1045)\end{array}$ \\
\hline Dummy Imperial & & & $\begin{array}{c}-0.2629 * * \\
0.0126\end{array}$ & & $\begin{array}{c}-0.5878 * * * \\
(0.0087)\end{array}$ \\
\hline Dummy Chase & & & & $\begin{array}{c}0.2382 * * * \\
(0.0053) \\
\end{array}$ & $\begin{array}{c}0.5634 * * * \\
(0.0001)\end{array}$ \\
\hline R-squared & 0.8422 & 0.8379 & 0.8380 & 0.8369 & 0.8350 \\
\hline Adjusted R-squared & 0.8413 & 0.8365 & 0.8367 & 0.8356 & 0.8329 \\
\hline Sum Squared Residual & 1815.6 & 2063.54 & 2114.6 & 2173.6 & 2199.04 \\
\hline Log Likelihood & -505.63 & -538.59 & -582.30 & -619.41 & -611.11 \\
\hline $\begin{array}{c}\text { Durbin-Watson } \\
\text { Statistic }\end{array}$ & 1.7320 & 1.7313 & 1.7442 & 1.7381 & 1.7524 \\
\hline \multicolumn{6}{|c|}{ ARCH - LM TEST } \\
\hline Constant & $\begin{array}{c}0.9642 * * * \\
(0.0000)\end{array}$ & $\begin{array}{c}0.9613^{* * *} \\
(0.0000)\end{array}$ & $\begin{array}{c}0.9617^{* * * *} \\
(0.0000)\end{array}$ & $\begin{array}{c}0.9718 * * * \\
(0.0000)\end{array}$ & $\begin{array}{c}0.9643 * * * \\
(0.0000)\end{array}$ \\
\hline Residual Squared & $\begin{array}{c}0.02960 \\
(0.587)\end{array}$ & $\begin{array}{c}0.0301 \\
(0.5760) \\
\end{array}$ & $\begin{array}{c}0.0295 \\
(0.5700)\end{array}$ & $\begin{array}{c}0.0246 \\
(0.6269) \\
\end{array}$ & $\begin{array}{c}0.0294 \\
(0.5620)\end{array}$ \\
\hline Observed $\mathrm{R}^{2}$ & $\begin{array}{c}0.2969 \\
(0.5858)\end{array}$ & $\begin{array}{c}0.3148 \\
(0.5747)\end{array}$ & $\begin{array}{c}0.3248 \\
(0.5687)\end{array}$ & $\begin{array}{c}0.2377 \\
(0.6258)\end{array}$ & $\begin{array}{c}0.3383 \\
(0.5608)\end{array}$ \\
\hline
\end{tabular}




\begin{tabular}{|c|c|c|c|c|c|}
\hline F - Statistics & $\begin{array}{c}0.2954 \\
(0.5871)\end{array}$ & $\begin{array}{c}0.3133 \\
(0.5760)\end{array}$ & $\begin{array}{c}0.3233 \\
(0.5700)\end{array}$ & $\begin{array}{c}0.2367 \\
(0.6269)\end{array}$ & $\begin{array}{c}0.3369 \\
(0.5620)\end{array}$ \\
\hline Observations & 339 & 348 & 373 & 392 & 392 \\
\hline
\end{tabular}

Note: Significance probabilities in parenthesis, *** (significant at 1\%) ** (significant at 5\%) and * (significant at $10 \%$ ).

From Table 5.0, it is clear that from the mean equation, the previous week's interbank rate significantly affects the current week's interbank rate. This is evidenced by the coefficient of Interbank (-1) for period 1 which is 0.9196 significant at 1 percent significance level. Similar results are replicated for the other periods and the overall model at large. The mean equation results indicate that the 91 Treasury bill rate positively and significantly affects the interbank market rate in all the periods. However, the results indicate that the effect rises significantly up in the stress times as compared to the stress free period. Prior to placement of any lender under receivership, the effect of 91 Treasury bill rate on interbank rate stands at 0.0373. This doubles to 0.0677 upon collapse of Dubai bank, 0.0635 upon collapse of Imperial bank and 0.0606 with placement of Chase bank under receivership. For the overall stresses combined, the effect of 91 Treasury bill rate on interbank rate volatility is 0.0358 . Both the Dubai bank dummy and the imperial bank dummy negative affect the interbank rates with only the imperial bank dummy being significant.

From the conditional variance equation results, the arch $1\left(\alpha_{1}\right)$ reveal that volatility clustering was high following the placement of Chase bank under receivership as compared to Dubai and imperial bank case. However, as for the persistence in the shock as measured by GARCH term $(\beta)$, it's clear that upon the occurrence of a financial stress, the persistence of volatility in the interbank market rises. For the period $1, \beta=0.9405$. However, upon financial stress the value of $\beta$ (s) for period 2 up to period 4 are close to unity. Therefore, volatility shocks at the interbank are long lived rather than transitory. This implies that the Central bank intervention to restore the efficiency of the interbank market in allocating liquidity does not solve the structural challenges within the interbank hence long lived shocks in the interbank market upon the occurrence of such banking industry shocks.

The Exponential GARCH captures the asymmetry at the interbank market which is measured by coefficient $\gamma \cdot \gamma=0.0381$ in absence of financial stress. However, in presence of financial stress, the measure of asymmetry rises significantly. Its significance reveal presence of asymmetry and thus bad and good news drive the interbank market. 
Table 6.0: Exponential GARCH results for Treasury bill market volatility analysis

\begin{tabular}{|c|c|c|c|c|c|}
\hline \multicolumn{6}{|c|}{ EGARCH $(1,1)$ Results - Treasury Bill Rates } \\
\hline \multicolumn{6}{|c|}{ Mean Equation } \\
\hline & Period 1 & Period 2 & Period 3 & Period 4 & Overall model \\
\hline Constant & $\begin{array}{c}0.1324 * * * \\
(0.0000)\end{array}$ & $\begin{array}{c}0.1271^{* * *} \\
(0.0000)\end{array}$ & $\begin{array}{c}0.1260 * * * \\
(0.0000)\end{array}$ & $\begin{array}{c}0.1135 * * * \\
(0.0000)\end{array}$ & $\begin{array}{c}0.1400 * * * \\
(0.0000)\end{array}$ \\
\hline $\begin{array}{c}\text { Treasury bill rate } \\
(-1)\end{array}$ & $\begin{array}{c}0.9436 * * * \\
(0.0000) \\
\end{array}$ & $\begin{array}{c}0.9452 * * * \\
(0.0000) \\
\end{array}$ & $\begin{array}{c}0.9423^{* * * *} \\
(0.0000) \\
\end{array}$ & $\begin{array}{c}0.9472 * * * \\
(0.0000)\end{array}$ & $\begin{array}{c}0.9419 * * * \\
(0.0000)\end{array}$ \\
\hline Interbank & $\begin{array}{c}0.0499 * * * \\
(0.0000)\end{array}$ & $\begin{array}{c}0.0474 * * * \\
(0.0000)\end{array}$ & $\begin{array}{c}0.0515^{* * * *} \\
(0.0000)\end{array}$ & $\begin{array}{c}0.0480 * * * \\
(0.0000)\end{array}$ & $\begin{array}{c}0.0507 * * * \\
(0.0000)\end{array}$ \\
\hline Dummy Dubai & & $\begin{array}{c}0.9362 * * * \\
(0.0080)\end{array}$ & & $\begin{array}{l}-0.0337^{*} \\
(0.0913) \\
\end{array}$ & $\begin{array}{c}1.2002 * * * \\
(0.0028)\end{array}$ \\
\hline Dummy Imperial & & & $\begin{array}{c}0.1360 * * \\
(0.0403)\end{array}$ & & $\begin{array}{c}-1.0096 * * * \\
(0.0138)\end{array}$ \\
\hline Dummy Chase & & & & & $\begin{array}{c}-0.2100 * * * \\
(0.0105)\end{array}$ \\
\hline \multicolumn{6}{|c|}{ Variance Equation } \\
\hline Constant & $\begin{array}{c}-1.2361^{* * *} \\
(0.0000)\end{array}$ & $\begin{array}{c}-1.2227 * * * \\
(0.0000)\end{array}$ & $\begin{array}{c}- \\
1.1050 * * * \\
(0.0000)\end{array}$ & $\begin{array}{c}-1.0659 * * * \\
(0.0000)\end{array}$ & $\begin{array}{c}-1.2545^{* * *} \\
(0.0000)\end{array}$ \\
\hline $\mathrm{ARCH}(1)\left(\alpha_{1}\right)$ & $\begin{array}{c}1.3097 * * * \\
(0.0000) \\
\end{array}$ & $\begin{array}{c}1.3375 * * * \\
(0.0000) \\
\end{array}$ & $\begin{array}{c}1.2683^{* * * *} \\
(0.0000) \\
\end{array}$ & $\begin{array}{c}1.2449 * * * \\
(0.0000)\end{array}$ & $\begin{array}{c}1.3332 * * * \\
(0.0000) \\
\end{array}$ \\
\hline Asymmetry $(\gamma)$ & $\begin{array}{c}0.8319 * * * \\
(0.0000)\end{array}$ & $\begin{array}{c}-0.2586 * * * \\
(0.0003)\end{array}$ & $\begin{array}{c}- \\
0.2346^{* * *} \\
(0.0007)\end{array}$ & $\begin{array}{c}-0.2768 * * * \\
(0.0001)\end{array}$ & $\begin{array}{c}0.8284 * * * \\
(0.0000)\end{array}$ \\
\hline GARCH $(1)(\beta)$ & & $\begin{array}{c}0.8503^{* * *} \\
(0.0000) \\
\end{array}$ & $\begin{array}{c}0.8719 * * * \\
(0.0000) \\
\end{array}$ & $\begin{array}{c}0.8725 * * * \\
(0.0000)\end{array}$ & $\begin{array}{c}0.2452 \\
(0.7016) \\
\end{array}$ \\
\hline Dummy Dubai & & $\begin{array}{c}0.3044 \\
(0.5269) \\
\end{array}$ & & $\begin{array}{l}-0.3230 * \\
(0.0637) \\
\end{array}$ & $\begin{array}{l}-0.1761 \\
(0.7920) \\
\end{array}$ \\
\hline Dummy Imperial & & & $\begin{array}{c}0.0163 \\
(0.9041)\end{array}$ & & $\begin{array}{c}-0.3642 \\
(0.1559)\end{array}$ \\
\hline \multicolumn{6}{|l|}{ Dummy Chase } \\
\hline R-squared & 0.9697 & 0.9696 & 0.9621 & 0.9619 & 0.9626 \\
\hline $\begin{array}{c}\text { Adjusted R- } \\
\text { squared }\end{array}$ & 0.9696 & 0.9693 & 0.9618 & 0.9616 & 0.9621 \\
\hline $\begin{array}{c}\text { Sum Squared } \\
\text { Residual } \\
\end{array}$ & 153.1402 & 169.3320 & 232.8156 & 234.4917 & 230.2463 \\
\hline Log Likelihood & -129.2375 & -139.8237 & -179.3197 & -194.2565 & -173.7698 \\
\hline $\begin{array}{c}\text { Durbin-Watson } \\
\text { Statistic } \\
\end{array}$ & 1.1044 & 1.1612 & 1.0020 & 1.0109 & 1.0311 \\
\hline \multicolumn{6}{|c|}{ ARCH - LM Test } \\
\hline Constant & $\begin{array}{c}1.0180 * * * \\
(0.0000)\end{array}$ & $\begin{array}{c}1.0199 * * * \\
(0.0000)\end{array}$ & $\begin{array}{c}1.0228 * * * \\
(0.0000)\end{array}$ & $\begin{array}{c}1.0197 * * * \\
(0.0000) \\
\end{array}$ & $\begin{array}{c}1.0117 * * * \\
(0.0000)\end{array}$ \\
\hline Residual Squared & $\begin{array}{l}-0.0188 \\
(0.7303) \\
\end{array}$ & $\begin{array}{c}-0.0208 * * * \\
(0.6987)\end{array}$ & $\begin{array}{l}-0.0252 \\
(0.6278) \\
\end{array}$ & $\begin{array}{l}-0.0254 \\
(0.6163) \\
\end{array}$ & $\begin{array}{l}-0.0193 \\
(0.7030) \\
\end{array}$ \\
\hline Observed $\mathrm{R}^{2}$ & $\begin{array}{c}0.1197 \\
(0.7293) \\
\end{array}$ & $\begin{array}{c}0.1509 \\
(0.6977) \\
\end{array}$ & $\begin{array}{c}0.2366 \\
(0.6267) \\
\end{array}$ & $\begin{array}{c}0.2515 \\
(0.6163) \\
\end{array}$ & $\begin{array}{c}0.1456 \\
(0.7030) \\
\end{array}$ \\
\hline F - Statistics & $\begin{array}{c}0.1191 \\
(0.7303)\end{array}$ & $\begin{array}{c}0.1501 \\
(0.6987)\end{array}$ & $\begin{array}{r}0.235497 \\
(0.6278)\end{array}$ & $\begin{array}{c}0.2527 \\
(0.6152)\end{array}$ & $\begin{array}{c}0.1463 \\
(0.7021)\end{array}$ \\
\hline Observations & 339 & 348 & 373 & 392 & 392 \\
\hline
\end{tabular}

Note: Significance probabilities in parenthesis, *** (significant at 1\%) ** (significant at 5\%) and $*$ (significant at $10 \%$ ). 
For the Treasury bill market, it is evidently clear that the previous week's rate significantly positive influences the current week's rate as given by Treasury bill (-1) coefficients in all the periods. However, looking at the effect of interbank market on the TB market, we find a unique outcome in that the interbank market positively and significantly affects the TB market. However, the change in of interbank market on TB market, is very minimal as we move from financial free situation to a situation of financial stress. This is opposite of the effect of TB market on interbank where we find that the effect of TB market on interbank rates doubles as we move from financial stress free situation to financial stress situation. On volatility, high volatility clustering is evidenced in all period as measured by $\left(\alpha_{1}\right)$. The persistence of volatility as measured by GARCH (1) ( $\beta$ ) changes minimal across all periods. This is opposite of the results of the EGARCH results for interbank market.

Further we apply the Threshold GARCH (TGARCH) model analysis to ascertain the presence or absence of leverage effect in the allocation of liquidity through the interbank market. From Table 6.0 results we deduce that placement of Imperial and chase bank under receivership negatively impacts on interbank rates though insignificant. The effect of Treasury bill rate on interbank market still remains to be high with the banking sector stress compared to banking sector stress - free period with the effect being high for Dubai bank dummy.

Table 7.0: Threshold GARCH results for interbank market volatility analysis

\begin{tabular}{|c|c|c|c|c|c|}
\hline \multicolumn{6}{|c|}{ TGARCH $(1,1)$ Results } \\
\hline \multicolumn{6}{|c|}{ Mean Equation } \\
\hline & Period 1 & Period 2 & Period 3 & Period 4 & Overall Period \\
\hline Constant & $\begin{array}{c}0.0465 \\
(0.4996)\end{array}$ & $\begin{array}{c}0.0451 \\
(0.5194)\end{array}$ & $\begin{array}{c}0.0332 \\
(0.6118)\end{array}$ & $\begin{array}{c}0.0371 \\
(0.5973)\end{array}$ & $\begin{array}{c}0.0601 \\
(0.4734)\end{array}$ \\
\hline Interbank (-1) & $\begin{array}{c}0.9425 * * * \\
(0.0000)\end{array}$ & $\begin{array}{c}0.9411 * * * \\
(0.0000)\end{array}$ & $\begin{array}{c}0.9316^{* * *} \\
(0.0000)\end{array}$ & $\begin{array}{c}0.9290 * * * \\
(0.0000)\end{array}$ & $\begin{array}{c}0.9400 * * * \\
(0.0000)\end{array}$ \\
\hline Treasury bill rate & $\begin{array}{c}0.0219 \\
(0.1539)\end{array}$ & $\begin{array}{c}0.0230 \\
(0.1366)\end{array}$ & $\begin{array}{c}0.0323 * * \\
(0.0459)\end{array}$ & $\begin{array}{l}0.0312 * * \\
(0.0482)\end{array}$ & $\begin{array}{c}0.0209 \\
(0.2518)\end{array}$ \\
\hline Dummy Dubai & & $\begin{array}{c}0.7120 \\
(0.7405)\end{array}$ & & & $\begin{array}{c}0.2326 \\
(0.6226)\end{array}$ \\
\hline Dummy Imperial & & & $\begin{array}{l}-0.3280 \\
(0.1086)\end{array}$ & & $\begin{array}{c}0.5982 \\
(0.7290) \\
\end{array}$ \\
\hline Dummy Chase & & & & $\begin{array}{c}0.0769 \\
(0.8770) \\
\end{array}$ & $\begin{array}{c}-0.8250 \\
(0.6338) \\
\end{array}$ \\
\hline \multicolumn{6}{|c|}{ Variance Equation } \\
\hline Constant & $\begin{array}{c}0.0150 * * * \\
(0.0000)\end{array}$ & $\begin{array}{c}0.0149 * * * \\
(0.0000)\end{array}$ & $\begin{array}{c}0.0203^{* * * *} \\
(0.0000)\end{array}$ & $\begin{array}{c}0.0155^{* * *} \\
(0.0000)\end{array}$ & $\begin{array}{c}0.0226 * * * \\
(0.0000)\end{array}$ \\
\hline $\mathrm{ARCH}(1)\left(\alpha_{1}\right)$ & $\begin{array}{c}0.5821 * * * \\
(0.0000)\end{array}$ & $\begin{array}{c}0.5636 * * * \\
(0.0000)\end{array}$ & $\begin{array}{c}0.6584 * * * \\
(0.0000) \\
\end{array}$ & $\begin{array}{c}0.5584 * * * \\
(0.0000)\end{array}$ & $\begin{array}{c}0.5910 * * * \\
(0.0000)\end{array}$ \\
\hline Asymmetry $(\gamma)$ & $\begin{array}{c}-0.4501 * * * \\
(0.0000)\end{array}$ & $\begin{array}{c}-0.4407 * * * \\
(0.0001)\end{array}$ & $\begin{array}{c}-0.3348 * * \\
(0.0155)\end{array}$ & $\begin{array}{c}-0.4365 * * * \\
(0.0000)\end{array}$ & $\begin{array}{c}-0.4332 * * * \\
(0.0002)\end{array}$ \\
\hline
\end{tabular}




\begin{tabular}{|c|c|c|c|c|c|}
\hline GARCH $(1)(\beta)$ & $\begin{array}{c}0.7102^{* * *} \\
(0.0000)\end{array}$ & $\begin{array}{c}0.7160^{* * *} \\
(0.0000)\end{array}$ & $\begin{array}{c}0.6340 * * * \\
(0.0000)\end{array}$ & $\begin{array}{c}0.7104 * * * \\
(0.0000)\end{array}$ & $\begin{array}{c}0.6791 * * * \\
(0.0000)\end{array}$ \\
\hline Dummy Dubai & & $\begin{array}{c}6.2118 \\
(0.3959) \\
\end{array}$ & & & $\begin{array}{c}0.4588 * * * \\
(0.0070) \\
\end{array}$ \\
\hline Dummy Imperial & & & $\begin{array}{l}-0.1893 \\
(0.1341)\end{array}$ & & $\begin{array}{c}3.5036 \\
(0.3396) \\
\end{array}$ \\
\hline Dummy Chase & & & & $\begin{array}{l}0.3065^{* *} \\
(0.0181) \\
\end{array}$ & $\begin{array}{l}-3.6763 \\
(0.3171) \\
\end{array}$ \\
\hline R-squared & 0.8406 & 0.8369 & 0.8381 & 0.8370 & 0.8358 \\
\hline Adjusted R-squared & 0.8397 & 0.8355 & 0.8367 & 0.8358 & 0.8337 \\
\hline $\begin{array}{c}\text { Sum Squared } \\
\text { Residual }\end{array}$ & 1833.290 & 2076.564 & 2113.876 & 2172.071 & 2187.943 \\
\hline Log Likelihood & -510.3273 & -538.7975 & -587.053 & -622.336 & -619.513 \\
\hline $\begin{array}{c}\text { Durbin-Watson } \\
\text { Statistic }\end{array}$ & 1.7556 & 1.7362 & 1.7689 & 1.7506 & 1.7641 \\
\hline \multicolumn{6}{|c|}{ ARCH - LM TEST } \\
\hline Constant & $\begin{array}{c}0.9360^{* * *} \\
(0.0000) \\
\end{array}$ & $\begin{array}{c}0.9339 * * * \\
(0.0000)\end{array}$ & $\begin{array}{c}1.0053^{* * *} \\
(0.0000)\end{array}$ & $\begin{array}{c}0.9469 * * * \\
(0.0000)\end{array}$ & $\begin{array}{c}0.9486 * * * \\
(0.0000)\end{array}$ \\
\hline Residual Squared & $\begin{array}{c}0.0549 \\
(0.3142) \\
\end{array}$ & $\begin{array}{c}0.0569 \\
(0.2904) \\
\end{array}$ & $\begin{array}{c}0.0024 \\
(0.9625) \\
\end{array}$ & $\begin{array}{c}0.0450 \\
(0.3748) \\
\end{array}$ & $\begin{array}{c}0.0420 \\
(0.4076) \\
\end{array}$ \\
\hline Observed $\mathrm{R}^{2}$ & $\begin{array}{c}1.0189 \\
(0.3128)\end{array}$ & $\begin{array}{c}1.1241 \\
(0.2890)\end{array}$ & $\begin{array}{c}0.0022 \\
(0.9624)\end{array}$ & $\begin{array}{c}0.7919 \\
(0.3735)\end{array}$ & $\begin{array}{c}0.6895 \\
(0.4063)\end{array}$ \\
\hline F - Statistics & $\begin{array}{c}1.0159 \\
(0.3142)\end{array}$ & $\begin{array}{c}1.1213 \\
(0.2904)\end{array}$ & $\begin{array}{c}0.0022 \\
(0.9625)\end{array}$ & $\begin{array}{c}0.7895 \\
(0.3748)\end{array}$ & $\begin{array}{c}0.6872 \\
(0.4076)\end{array}$ \\
\hline Observations & 339 & 348 & 373 & 392 & 392 \\
\hline
\end{tabular}

Note: Significance probabilities in parenthesis, *** (significant at 1\%) ** (significant at 5\%) and * (significant at 10\%).

Within the TGARCH model leverage effect is captured by $\alpha_{1}$ and $\alpha_{2}$ which measure the bad news and good news on interbank market respectively. The sum of $\alpha_{1}$ and $\alpha_{2}$ measures the effect of bad news. For conditional variance equation, the coefficient $\beta$ captures the degree of persistence of shocks while the sum of $\alpha+\beta$ give the persistence of shocks. The results posit that bad news in the event of banking industry stress impacts the interbank market more even with the Treasury bill rate market's intervention compared to good news of the same magnitude signifying presence of leverage effect in the interbank market.

Table 8.0: Threshold GARCH results for Treasury bill market volatility analysis

\begin{tabular}{|c|c|c|c|c|c|}
\hline \multicolumn{7}{|c|}{ TGARCH (1, 1) Results - Treasury Bill Rates } \\
\hline & Period 1 & Period 2 & Period 3 & Period 4 & Overall model \\
\hline \multirow{2}{*}{ Constant } & $0.0848^{*}$ & $0.1243^{* * *}$ & $0.0894^{* * *}$ & $0.1028^{* * *}$ & $0.3412^{* * *}$ \\
& $(0.0770)$ & $(0.0000)$ & $(0.0007)$ & $(0.0000)$ & $(0.0004)$ \\
\hline \multirow{2}{*}{ Treasury bill rate (-1) } & $0.9570^{* * *}$ & $0.9459^{* * *}$ & $0.9347^{* * *}$ & $0.9539^{* * *}$ & $0.9289^{* * *}$ \\
& $(0.0000)$ & $(0.0000)$ & $(0.0000)$ & $(0.0000)$ & $(0.0000)$ \\
\hline \multirow{2}{*}{ Interbank } & $0.0400^{* * *}$ & $0.0465^{* * *}$ & $0.0664^{* * *}$ & $0.0426^{* * *}$ & $0.0421^{* * *}$ \\
& $(0.0000)$ & $(0.0000)$ & $(0.0000)$ & $(0.0000)$ & $(0.0000)$ \\
\hline \multirow{2}{*}{ Dummy Dubai } & & $0.8933^{* *}$ & & & $1.0096^{* * *}$ \\
& & $(0.0166)$ & & & $(0.0000)$ \\
\hline
\end{tabular}




\begin{tabular}{|c|c|c|c|c|c|}
\hline Dummy Imperial & & & $\begin{array}{c}0.1588 * * * \\
(0.0324)\end{array}$ & & $\begin{array}{c}-1.1063 * * * \\
(0.0000)\end{array}$ \\
\hline Dummy Chase & & & & $\begin{array}{c}-0.0494 * * * \\
(0.0031)\end{array}$ & $\begin{array}{c}0.0972 \\
(0.5342)\end{array}$ \\
\hline \multicolumn{6}{|c|}{ Variance Equation } \\
\hline Constant & $\begin{array}{c}0.1354^{* * *} \\
(0.0000)\end{array}$ & $\begin{array}{c}0.0102 * * * \\
(0.0000)\end{array}$ & $\begin{array}{c}0.0052 * * * \\
(0.0000)\end{array}$ & $\begin{array}{c}0.0042 * * * \\
(0.0010)\end{array}$ & $\begin{array}{c}0.2510 * * * \\
(0.0000)\end{array}$ \\
\hline $\mathrm{ARCH}(1)\left(\alpha_{1}\right)$ & $\begin{array}{c}0.5659 * * * \\
(0.0000)\end{array}$ & $\begin{array}{c}1.9011 \\
(0.0000) \\
\end{array}$ & $\begin{array}{c}1.2267 * * * \\
(0.0000)\end{array}$ & $\begin{array}{c}1.3823^{* * * *} \\
(0.0000)\end{array}$ & $\begin{array}{c}0.4483^{* * *} \\
(0.0000)\end{array}$ \\
\hline Asymmetry $(\gamma)$ & $\begin{array}{c}0.1327 \\
(0.6164)\end{array}$ & $\begin{array}{c}1.0177 * * * \\
(0.0214)\end{array}$ & $\begin{array}{c}0.7181^{* * *} \\
(0.0052)\end{array}$ & $\begin{array}{c}1.5065^{* * * *} \\
(0.0000)\end{array}$ & $\begin{array}{c}0.2202 \\
(0.2499) \\
\end{array}$ \\
\hline GARCH (1) $(\beta)$ & $\begin{array}{l}-0.0035 \\
(0.7148) \\
\end{array}$ & $\begin{array}{c}0.0673^{* * *} \\
(0.0000)\end{array}$ & $\begin{array}{c}0.2490 * * * \\
(0.0000)\end{array}$ & $\begin{array}{c}0.2341^{* * *} \\
(0.0000)\end{array}$ & $\begin{array}{l}-0.0089 \\
(0.8200)\end{array}$ \\
\hline Dummy Dubai & & $\begin{array}{c}0.8441 \\
(0.7025)\end{array}$ & $\begin{array}{c}0.0400 \\
(0.6107)\end{array}$ & & $\begin{array}{c}0.0895 \\
(0.4936)\end{array}$ \\
\hline Dummy Imperial & & & & & $\begin{array}{c}-0.0434 \\
(0.8057) \\
\end{array}$ \\
\hline Dummy Chase & & & & $\begin{array}{l}-0.0032 \\
(0.6031)\end{array}$ & $\begin{array}{c}-0.2698 * * \\
(0.0304) \\
\end{array}$ \\
\hline R-squared & 0.9697 & 0.9696 & 0.9614 & 0.9621 & 0.9643 \\
\hline Adjusted R-squared & 0.9695 & 0.9694 & 0.9611 & 0.9618 & 0.9639 \\
\hline Sum Squared Residual & 153.2099 & 169.1395 & 236.5859 & 233.5247 & 219.7956 \\
\hline Log Likelihood & -188.8387 & -138.5437 & -185.6090 & -189.9136 & -275.4887 \\
\hline Durbin-Watson Statistic & 1.1140 & 1.1619 & 0.9916 & 1.0123 & 1.0552 \\
\hline \multicolumn{6}{|c|}{ ARCH - LM Test } \\
\hline Constant & $\begin{array}{c}0.8320 * * * \\
(0.0000)\end{array}$ & $\begin{array}{c}1.0367 * * * \\
(0.0000)\end{array}$ & $\begin{array}{c}1.0334^{* * *} \\
(0.0000)\end{array}$ & $\begin{array}{c}1.0422^{* * *} \\
(0.0000)\end{array}$ & $\begin{array}{c}0.6643^{* * *} \\
(0.0000)\end{array}$ \\
\hline Residual Squared & $\begin{array}{c}0.0029 \\
(0.9569)\end{array}$ & $\begin{array}{c}-0.0385 \\
(0.4748)\end{array}$ & $\begin{array}{c}-0.0366 \\
(0.4817)\end{array}$ & $\begin{array}{c}-0.0443 \\
(0.3822)\end{array}$ & $\begin{array}{c}0.0413 \\
(0.4092)\end{array}$ \\
\hline Observed $\mathrm{R}^{2}$ & $\begin{array}{c}0.0029 \\
(0.9567) \\
\end{array}$ & $\begin{array}{c}0.5140 \\
(0.4734) \\
\end{array}$ & $\begin{array}{c}0.4959 \\
(0.4817) \\
\end{array}$ & $\begin{array}{c}0.7677 \\
(0.3809) \\
\end{array}$ & $\begin{array}{c}0.6850 \\
(0.4079) \\
\end{array}$ \\
\hline F - Statistics & $\begin{array}{c}0.0029 \\
(0.9569) \\
\end{array}$ & $\begin{array}{c}0.5118 \\
(0.4748) \\
\end{array}$ & $\begin{array}{c}0.4979 \\
(0.4804)\end{array}$ & $\begin{array}{c}0.7653 \\
(0.3822) \\
\end{array}$ & $\begin{array}{c}0.6827 \\
(0.4092) \\
\end{array}$ \\
\hline Observations & 339 & 348 & 373 & 392 & 392 \\
\hline
\end{tabular}

Note: Significance probabilities in parenthesis, *** (significant at 1\%) ** (significant at 5\%) and * (significant at $10 \%$ ).

From table 8.0 results we deduce that placement of Imperial and chase bank under receivership negatively affected on Treasury bill market though significantly. However, as opposed to the previous results, the effect of interbank market on Treasury bill rate declines significantly with the banking sector stress compared to banking sector stress - free period.

\section{Conclusion}

The paper aims at evaluating the effect of policy and market reaction towards promoting efficiency on the interbank market in the times of stress in the banking industry. The paper uses treasury bill-interbank market link 
buttressed by the argument that in times of interbank market stress, the Treasury bill market is the resort of the lender banks seeking the next nearest liquid asset. As liquidity challenges in the "small" bank segment of the industry arising a lender being put under statutory management leads to (near) inter-bank market freeze, lender banks seek to pack their liquidity in sort end of the risk free assets - the 91-day Treasury bills in our case.

The findings of the data analysis indicate that 91-day Treasury bill rate positively and significantly affects the interbank market rate. Results for period prior to banking industry stress and after the industry stress indicate that the effect of 91-day Treasury bill rate on interbank market rate rises significantly upon the occurrence of banking industry stress as compared to the stress free period. In fact, the results indicates that the effect of 91-day Treasury bill rate on interbank rate doubles upon the placement of a lender under receivership. On the volatility front, banking industry stress in awake of collapse of a lender triggers high volatility clustering. As evidenced by results for EGARCH model placement of Chase bank under receivership portrayed high volatility clustering as compared to Dubai and imperial bank case.

From the results we conclude that volatility shocks at the interbank are long lived rather than transitory implying that the intervention by the Central bank to restore efficiency in the interbank market in allocating market liquidity by using open market operation tools such as treasury bills upon the occurrence of banking industry stress is deficient of solving structural challenges within the interbank hence long lived shocks in the interbank market upon the occurrence of such banking industry shocks. Such interventions only helps the market to move towards near normal situation but fails to address structural weaknesses of the interbank market. In terms of information asymmetry, our results suggests that bad news significantly impacts on interbank market compared to good news of the same magnitude hence an evidence for leverage effect. Further we note that even with the intervention by the CBK, the leverage effect in the interbank market still remains.

\section{References:}

1. Acharya, V., Yorulmazer, T., 2008. Cash-in-the-market pricing and optimal resolution of bank failures. Review of Financial Studies, forthcoming.

2. Berrospide, J.M., Black, L. K. and Keeton, W. R., (2016), "The Cross-Market Spill of Economic Shocks through Multimarket Banks”, Journal of Money, Credit and Banking, Vol 48, No. 5, pp. 597 - 988, August. 
3. Castiglionesi F., Feriozzi F., Loranth G., and Pelizzon L., (2014) Liquidity Coinsurance and Bank Capital, Journal of Money, Credit and Banking, Vol 46, No. 2 - 3, pp. 409 - 443, March - April.

4. Danielsson J., James K. R., Valenzuela M., and Zer L., (2016), Can We Prove a Bank Guilty of Creating Systemic Risk? A Minority Report, Journal of Money, Credit and Banking, Vol 48, No. 4, pp. 795 - 812, June.

5. Deb, P., (2016), "Market Friction, Interbank Linkages and Excessive Interconnection”, IMF Working Paper WP/16/180, August.

6. Diamond, D., Rajan, R., 2005. Liquidity shortages and banking crises. Journal of Finance, 60, 615-647.

7. Diamond, D., Rajan, R., 2008. Illiquidity and interest rate policy. Working paper, University of Chicago.

8. Gorton, H., Huang, L., 2004. Liquidity, efficiency and bank bailouts. American Economic Review, 94, 455-483.

9. Gorton, H., Huang, L., 2006. Banking Panics and Endogeneity Coalition Formation. Journal of Monetary Economics, 53, 16131629.

10. Dornbusch, R., (1976), Expectations and Exchange Rate Dynamics, the Journal of Political Economy, Vol. 84 pp. 1161 - 1176.

11. Engle, R. F. (1982).Autoregressive conditional heteroscedasticity with estimates of U.K inflation. Econometrica, 50, 987 - 1008.

12. Engle, R. F. \& Bollerslev, T. (1986), Modelling the persistence of conditional variances, Econometric Reviews, 5, 1-50.

13. Holmstrom, B., Tirole, J., 1998. Private and public supply of liquidity. Journal of Political Economy 106, 1-40.

14. Kim K., (2014), A Price-Differentiation Model of the Interbank Market and Its Empirical Application Department of Economics, Massachusetts Institute of Technology, December.

15. Nelson, D. B. (1991), 'Conditional heteroskedasticity in asset returns: A new approach', Econometrica, 59, 347-370.

16. Oduor J., Sichei, M. M., Tiriongo S. K., and Shimba C., (2014), Segmentation and efficiency of the interbank market and their implication for the conduct of monetary policy, African Development Bank Group Working Paper Series, No. 202, April.

17. Zakoian, J. M. (1994), Threshold heteroskedastic models, Journal of Economic Dynamics and Control, 18(5), 931-955. 